\title{
Swedish Books, recently published in the field of American culture
}

Geography and Travel.

Gullers, K. W. \& Pers, Anders H.: Sverige - USA. Fakta bilder, tankar kring förbindelserna Sverige - USA. (Sweden - USA. Facts, pictures, thoughts concerning the relationship Sweden - USA). Photo by K. W. Gullers. Text by Anders II. Pers. 79 p. TIl. Stockholm 1969.

Gullers, K.W. - Shole, Robert: USA - Sweden. Photo by K. W. Gullers. Text by Robert Shole. Stockholm 1969.

Lindmarker, Ingmar: Ett litet Amerilta. Rapport frăn amerikansk förstad. (A small America. Report from an American Suburb.) 171 p. I11. Stockholm 1968. Persson, Hasse: New Yotk, kontrasternas stad. En bildberattelse. (New Yorlc a city of contrasts. A pictorial story.) 156 p. Ill. Halmstad 1969.

Sundstedt, Arthur: Med Greyhoundbuss runt USA. Tiotusen engelska mil på trettio dagar. (By Greyhound-bus around the USA. Ten thousand miles in thirty days.) 143 p. Ill. Stockholm 1969.

History, immigration, emigration, and minorities in America.

Adler-Karlsson, Gunnar: Det militar- industriella brodraskapet i USA. (The military-industrial brotherhood in the USA). Strategisk bulletin 6. 1969. 34 p. Amerika (Edited and commented by) Göran Rystad. 183 p. Problem i modern historia. Lund 1969.

Amerikaemigrationen i dokument. (The emigrations to America in documents). Collected by Albin Widén. 169 p. IIl. Stockholm 1969.
Amerika förr och nu. (America yesterday and today.) By Göran Graninger, Peter Modie, Jan Moen, Sven Tagil. 216 p. Ill. Lund 1969.

Ander, Gunnar \& Runesiam, Axel: Sagt och skrivet. USA. (Said and written. USA.) Ill. Stockholm 1968.

Amberg, Teddy: Revolutionara rörelser i USA. (Revolutionary movements in the USA.) 126 p. Stocltholm 1968.

Dablberg, Hans: Vart glr USA under Nixon? (Where will the USA go under Nixon?) Aktuell debatt $\mathrm{nr} 3.44 \mathrm{p}$. Stockholm 1969.

Dilemmat Amerika. En bok om makt. (The dilemma of America. A book about power.) Edited by Göran Sarring and Erik Jansson with contribution by Gunnar Adler-Karlsson. 139 p. III. Stockholm 1968.

Lindmarker, Ingmar: Lyndon Johnsons »Great Society» i kris. (Lyndon Johnson's »Great Society), in crisis.) Världspolitikens dagsfrlgor, 10/11 1967.

Nilsson, Fred: Emigrationen från Stockholm till Nordamerilra 1880-1893. (The emigration from Stockholm to North America 1880-1893.) (With and English summary.) Studia Historica Upsaliensia 31.393 p. Ill. Stockholm 1970.

Nilsson, Ulf: Robert Kennedy. 158 p. III. Malmo 1967.

Nilsson, Ulf: USA-68, våld och val. (USA -68, violence and election.) 195 p. Stockholm 1968.

Pebrson, Gerda: Drommen om Amerilca. (The dream about America.) 80 p. III. Stockholm 1969. 
Runeby, Nils: Den nya varlden och den gamla. Amerikabild och emigrationsuppfattning i Sverige 1820-1860. (The new world and the old. Image of America and concept of emigration in Sweden 1820-1860.) (With and English summary.) Studia Historica Upsaliensia 30. 501 p. Stockholm 1969.

Rystad, Göran: Nordamerikanska inbördeskriget. (The American Civil War.) 229 p. 111. Lund 1968.

Sjoberg, Suen: Utvandringen till Amerika. (The emigration to North America.) Pedagogic consultation: Börje Dahl. 79 p. Ill. Stockholm 1968.

Stiernlöf, Sture: Det brinnande korset. En bok om Sydstaterna. (The burning cross. A book about the South.) $183 \mathrm{p}$. Ill. Stockholm 1968.

Tingsten, Herbert: Dagbok från Amerika. (A diary from America.) $218 \mathrm{p}$. Stockholm 1968.

Vad gjorde farfar i Amerika? Stämningar kring utvandringen till den nya varlden. (What did grand-father do in America? Feelings about the emigration to the new world.) By Jan Olsheden, Stellan Olsson. 159 p. 111. Stockholm 1968.

Ostling, Sven: Slavhandeln over Atlanten, (The slave-trade over the Atlantic.) 63 p. Ill. Stockholm 1868.

American foreign policy and foreign relations.

Adler-Karlsson, Gunnar: Western Economic Warfare 1947-1967. A Case Study in Foreign Economic Policy. With a Foreword by Gunnar Myrdahl. (Academic dissertation, Stockholm University) 319 p. Stockholm 1968.

Beckman, Staffan: Palestina och USAimperialismen. (Palestine and the USimperialism) 185 p. Ill. Stockholm 1969.
Mörner, Magnus: Latinamerika och Förenta Staterna. (Latinamerica and the USA.) Världspolitikens dagsfrilgor, 1 1969.

Nilsson, Sam: Om klyftor mellan Västeuropa och USA. (On discrepancies between Western Europe and the USA.) 51 p. Varldspolitikens dagsfrågor, 5/6 1969.

Om Förenta Staternas imperialism. Rapport från ett internationellt seminarium arrangerat av Unga filosofer. (On the imperialism of the United States. Report from an international seminar arranged by Unga filosofer.) Edited by Olle af Geijerstam. 148 p. Stockholm 1969.

Palme, Olof: USA-kriget i Vietnam. (The US war in Vietnam.) 16 p. Tll. Utblick. Edited by the Swedish Socialdemocratic Youth-Organization, SSU. Frihet, nr 8. Stockholn 1968.

Weiss, Peter \& Palmstierna, Gunilla: Rapport om Forenta Staternas förstärkta angrepp mot Nordvietnam efter den 31 mars 1968. (Report on the reinforced attacs on North Vietnam by the Unites States after March 31, 1968.) The Swedish edition redacted together with Erik Eriksson. 48 p. Staffanstorp 1968.

\section{Ethnography.}

Anell, Bengt: Running Down and Driving of Game in North America. 129 p. IIl. Studia Ethnographica Upsaliensia. Nr 30. 1969.

\section{Literatuve and culture, General.}

Ambiörnson, Ronny - Andersson, Gunnar - Elzinga, Aant: Forskning och politik i Sverige, Sovjet och USA. (Research and politics in Sweden, the Sovietunion and the USA.) 263 p. Stockholm 1969. 
Delblanc, Sven: Åsnebrygga. Dagboksroman. (A diary-novel from America.) 208 p. Stockholm 1969.

\section{Bibliography.}

Bengtson, Göran: Den amerikanska romanen efter fiirsta världskriget. Från Hemingway till Joseph Heller. (The American novel after the Second World War. From Hemingway to Joseph Heller.) 66 p. Lund 1969.

Brain Drain and Brain Gain. A Bibliography on Migration of Scientists,
Engineers, Doctors, and Students. Publ. by the) Research Policy Program, Lund, Sweden. 48 p. Forskningspolitiska programmet. Lund 1967.

Melin, Karin: Vietnamkonflilrten i svensk opinion 1954-1968. (The Vietnam-conflict in Swedish opinion 1954 -1968.) A bibliography. Published in the series "Dokumentation och Fakta" from the Royal Library. Bibliografiska institutet, Stockholm, nr 1. Stockholm 1969.

American Studies Conference, June 23-27, 1971.

Nordic Academy of Kungalv, Sweden.

\section{»The US in the 70'. Roles and Realities»}

A conference under the auspices of NAAS and the Nordic Academy of Kungalv. The conference is given for scholars in American studies or scholars with interest in American cultural problems. University instructors, adult educational teachers, college instructors among others. As American researchers will participate, the conference will be held in English. Simultaneous interpretation can be arranged. After every lecture a general discussion will be held.

Program subject topics:

Prof. Daniel Boorstin, Washington DC: »State of the union,. Prof. Peter Rose, Smith College: Racial Roles in the US.

Prof. Knud Erik Svendsen, Köpenhamn and Tanzania: US and the Third World.

An excursion to Marstrand will be arranged.

A detailed program can be obtained from the Academy from February 1.

Fee: Sw. Kr. 150: -

Closing date for applications: June 1.

The Nordic Academy of Kungälv

S-442 00 Kungälv

Sweden 